\title{
CONSUMER BUYING PSYCHOLOGY AND BRAND PERCEPTION: INFLUENCE OF WORD OF MOUTH COMMUNICATION
}

\author{
Dr. Rashmi Rai \\ Assistant Professor, School of Business and Management Christ (Deemed to be) University \\ Bannerghatta Main Rd, Pai Layout, Hulimavu,, Bengaluru, Karnataka \\ Dr. Shruti Tripathi \\ Associate Professor, Amity International Business School \\ Amity University, Noida, Uttar Pradesh
}

\begin{abstract}
Word-of-mouth Communication (WOM) has recently gained momentum in almost every operating industry in the world. WOM can be seen as a firms' intentional influencing of consumer-to-consumer communications about the firms' products. This study's primary objective was to determine whether there was any significant relationship between Word-of-mouth communication and Consumer buying behaviour specificity to the Indian cosmetics industry. The study was conducted with a sample size of 163 women, hailing mainly from South Indian cities, out of which Bangalore was predominant. The results of this study are to the Indian urban/metro population. The research eventually concluded a significant correlation between WOM and Consumer buying Behaviour, wherein consumer behaviour was measured in terms of Brand Perception, Search \& Evaluation effort, and Risk Reduction. WOM's correlation with each of these aspects was positive and high, indicating a direct and strong relationship.
\end{abstract}

Keywords: WOM, Brand Perception, Risk Reduction, Consumer Buying Behavior, Risk Reduction

\section{INTRODUCTION}

Word-of-mouth Communication (WOMC) has recently gained momentum in almost every operating industry in the world. WOMC can be seen as a firms' intentional influencing of consumer-to-consumer communications about the firms' products. (Robert V. Kozinets, 2010). The concept of Word of mouth can also be defined as "consumer to consumer communication" about goods and services.

The tool has a persuasive connotation, especially in the diffusion of information about new products (Dean \& Lang, 2008). Word-of-mouth is a huge driver of sales and revenue for any brand. WOM occurs in social talks; such talks produce almost 3.3 billion brand impressions each day (Keller \& Libai, 2009). Every such social interaction result in the transfer of data between individuals which allows the spread of words concerning the brand (Chauhan, Banerjee \& Banerjee, 2019). (Sen, 2017). Changing researchers contended that cosmetic industries could easily change consumers' buying behaviour by creating awareness and building strong perceptions through advertising.

\section{LITERATURE REVIEW}

(Kotler \& Keller, 2006) defines the concept of word of mouth as "personal communication about a product between target buyers and neighbours, friends, family members, and associates." It involves data transfer between consumers, which results in the promotion of a particular product.

Taking the example of television advertisements, today we have hundreds of television channels, each airing hundreds of ads. How humans are communicating now has become more focused and organized, allowing information and messages to be passed across various target groups. This is said to create a 'buzz.' Buzz marketing is also an effective form of marketing (Barber \& Wallace, 2018). One of the most profound reasons for the growth in WOM Communication is its phenomenon of low costs. There is almost no investment required in WOM Communication, and it also starts generating results almost immediately, primarily when undertaken through technology or the internet (Trusov, Bucklin, \& Pauwels, 2009). Instead of tossing away tons of money towards expensive television advertisements and billboard ads, companies 
can focus on building a better brand image, which will inadvertently result in WOMM (Word of Mouth Marketing) communication. Companies can also indulge in WOM communication campaigns, which include induced WOM among various social networks.

Gabeur (2015) says that WOM provides large quantities of information to the consumers, which influences decisions significantly. This influence is more potent than that of the information obtained from traditional forms of marketing, like advertising and sales promotion campaigns. Walker (1995) also stresses the effect that WOM has on consumer decision making. Almost $40 \%$ of Americans indulge in WOM before acquiring certain services like a doctor, mechanic, or a lawyer. Godes \& Mayzlin (2004) argue that due to WOM's wide success, companies need to measure WOM as a market mechanism that affects their overall marketing strategy.

\section{Positives and Negatives of WOM communication}

Whenever consumers express themselves concerning the usage or their response to a particular product or service, it formulates a WOM process. WOM can be positive or negative. The method by which consumers receive positive feedback and negative feedback might vary. But even this has differential views. East, Hammond, \& Lomax (2008) found that positive WOM had a higher level of influence on customers' perception of the brand, resulting in more consumption.

In contrast, the negative WOM didn't have a substantial impact. On the other hand, Charlett, Garland, \& Marr (1995) found that positive and negative WOM on consumer perception and purchase behaviour was the same. This study established that WOM's form didn't make a difference to its influence on buying behaviour.

\section{Drivers of WOM Communication}

Schiffman \& Kanuk (2015) explained the opinion-leader theory, where opinion seekers depend on leaders for information. They claimed that customers' motives to indulge in WOM are to reduce search time, find suitable products or services, and reduce the risk of a wrong choice.
(Paul \& Uikey, 2017, p. 60) in their research, everyone wants to look good and presentable, whether past or current times, fashion has always been involved in one's life and personality. They also keep looking for new ways that introduced unknown style subsequent motive or reason to indulge in WOM can be derived from the theory of cognitive dissonance. When consumers settle on a particular product, they face a' cognitive incongruence' or a dilemma in simple terms if they are presented with information about various other alternatives and offers.

Another motive can be factored through sociopsychological research, which is based on the virtual or internet community, to online consumers who become essential members of the user group for a particular product, from the need to feel accepted.

Chung \& Darke (2006) also states that apart from promoting WOM, self-relevant products also allow consumers to self-promoters. Consumers often feel the need to fulfil selfinterest, and their actions are by the image they want to portray themselves. They adjust their behaviours in that respect.

Studies indicate purchasers are ready to guarantee a fake watch they possessed was a certified name mark item to make a positive impression and increase economic wellbeing. These discoveries propose purchasers may likewise be enticed to overstate when they give WOM, particularly when buyers claim and relate to the item. In particular, Fazio \& Towles-Schwen (1999) analyzed WOM's valence for self-applicable items and practical items, where these item types were at first evaluated as similarly good. On the off chance that shoppers are exact when giving WOM, no distinction in WOM valence should be seen between the two item types because there is no distinction in the underlying assessments. Any propensity for shoppers to give progressively positive WOM for self-important items over utilitarian items can be ascribed to predisposition along these lines.

The most common drivers of WOM are said to be customer satisfaction and involvement. Customers who are happy or disappointed with a product or service are usually vocal about their thoughts; this furthers WOM. They may indulge in WOM communication 
purposely or involuntarily. But there are cases when consumers do not vocalize their contentment or disappointment. In such cases, involvement becomes an important criterion, and the factor contributing to involvement is perceived risk. The risk associated with buying a particular product may drive consumers to confer with others; opinions and experiences. Consumers, especially those with limited spending capacity, are conscious about their spending decisions; this makes them aware of the risks surrounding purchasing any product or service. This justifies their need to be cautious and take preventive steps to minimize that risk. They do this by considering other people's suggestions and opinions (Kraigher-Krainer, Überwimmer, Costa, \& Zehetner, The Hidden Impact of Word-Of-Mouth: A System Dynamics Approach, 2017).

\section{METHODOLOGY}

Most companies incur considerable costs in trying to create apt advertisements for their products. In the cosmetic industry, there's neck-to-neck competition that exists. But companies do not consider essentially free marketing, that is, word of mouth marketing. The impact that such marketing has on consumers is yet to be actively quantified.

The present study follows a descriptive or diagnostic research design.

Objectives of the study were to theorize how consumers process WOM information in decision-making; the aim of the study was also to find out how companies can incorporate WOM as a regular part of their marketing strategy and to understand precisely why consumers indulge in WOM (risk reduction, lesser effort).

\section{Hypothesis Formulation}

This paper has the objective of identifying the effect of Word of mouth on consumer psychology and buying behavior while buying cosmetic products

Brand perception forms an integral part of WOMM. The image that a consumer holds of a brand influences their buying behavior towards it. (Qvist, 2009) ascertains that WOM's impact on the brand perception or image of a company is also of great importance. Thus, this hypothesis was formulated
H1: There is a relationship between WOM and Brand Perception

A subsequent motive or reason to indulge in WOM can be derived from the theory of cognitive dissonance. Even though consumers have settled on a particular product, when presented with information about various other alternatives and offers, they face a 'cognitive incongruence' or a dilemma, in simple terms. They start to wonder whether they should have gone with the recommendations that they rejected. Thus, this study made the following hypothesis:

H2: There is a relationship between WOM and Search \& Evaluation by consumers

The risk associated with buying a particular product may drive consumers to confer with others; opinions and experiences. Consumers, especially those with limited spending capacity, are conscious about their spending decisions; this makes them aware of the risks surrounding purchasing any product or service. Hence this hypothesis was established

H3: There is a relationship between WOM and Reduction of Risk by consumers

In each case, the study tests the causal relationship between the two considered variables to understand which variable influences the other and if there is any such causality in the first place. This automatically defines the dependent and independent variable in each of the cases.

The questionnaire was used for primary data collection. It consisted of 4 specific parts. The first was related to demographics. Since the research was dealing with the cosmetic industry, the demographics mainly consisted of women. The second segment consisted of cosmetic industry-specific questions to understand whether they indulge in WOM and buy based on such reviews. It also ascertained the impact on brand perception. This established the primary objective. The third segment was about whether reducing search and evaluation effort is a consumer's motivation to read comments before purchasing a cosmetic product. The fourth segment dealt with questions to determine if lowering risk is a consumer's motivation to read words before buying cosmetics. 
The questionnaire was distributed to 210 women, but the completed questionnaire received from the respondents was only 163, restricting our sample size only to that number across Bangalore and other south Indian states.

\section{RESULTS}

\section{Reliability Tests of Factors}

The factors were tested for reliability using the SPSS software. The reliability innately depends on factors like sample size and variance of data. It gives an insight into the genuineness of the data collected.

Table 4.1: Reliability Statistics

\begin{tabular}{|l|c|c|}
\hline Variable & $\begin{array}{c}\text { Cronbach's } \\
\text { Alpha }\end{array}$ & $\begin{array}{c}\text { N of } \\
\text { Items }\end{array}$ \\
\hline WOM & .764 & 9 \\
\hline Brand Perception & .713 & 4 \\
\hline Search \& Evaluation & .770 & 3 \\
\hline Reducing Risk & .707 & 4 \\
\hline
\end{tabular}

Source: Author's Calculations

The Cronbach's Alpha value is observed to measure reliability, and any value greater than 0.7 is considered to be good. As indicated from the table 4.1the data collected in this study under all the factors are highly reliable.

\section{Correlation Tests}

The study tests correlation using SPSS, through Bivariate Pearson's correlation tests.
The Pearson's correlation coefficient is observed to determine whether there is a positive or negative; high of low correlation. The significance value is also observed to determine the significance of the results. The results are significant if the value is less than 0.005 .

The study tests the correlation between 3 sets of factors:

a. Correlation between WOM and Brand Perception

$\mathrm{H}_{0}$ : There is no significant correlation between WOM and Brand Perception

$\mathrm{H}_{1}$ : There is a significant correlation between WOM and Brand Perception

From the above table, the Pearson's correlation coefficient between WOM and Brand Perception is 0.679 . this indicates a positive correlation, which means a direct relationship. The results are significant as the 2-tailed significance value is 0.000 , which is less than 0.005 .

Therefore, the null hypothesis is rejected, and $\mathrm{H}_{1}$ is accepted.

b. Correlation between WOM and Search \& Evaluation

$\mathrm{H}_{0}$ : There is no significant correlation between WOM and Search \& Evaluation

$\mathrm{H}_{2}$ : There is a significant correlation between WOM and Search \& Evaluation

Table 4.2: Correlation Table

\begin{tabular}{|l|l|c|c|c|c|}
\hline \multicolumn{2}{|c|}{} & WOM & $\begin{array}{c}\text { Brand } \\
\text { Perception }\end{array}$ & $\begin{array}{c}\text { Search \& } \\
\text { Evaluation }\end{array}$ & $\begin{array}{c}\text { Reducing } \\
\text { Risk }\end{array}$ \\
\hline \multirow{4}{*}{ WOM } & Pearson Correlation & 1 & $.679^{* *}$ & $.729^{* *}$ & $.676^{* *}$ \\
\cline { 2 - 6 } & Sig. (2-tailed) & & .000 & .000 & .000 \\
\cline { 2 - 6 } & $\mathrm{N}$ & 163 & 163 & 163 & 163 \\
\hline \multirow{3}{*}{$\begin{array}{l}\text { Brand } \\
\text { Perception }\end{array}$} & Pearson Correlation & $.679^{* *}$ & 1 & $.666^{* *}$ & $.633^{* *}$ \\
\cline { 2 - 6 } & Sig. (2-tailed) & .000 & & .000 & .000 \\
\cline { 2 - 6 } & $\mathrm{N}$ & 163 & 163 & 163 & 163 \\
\hline \multirow{3}{*}{$\begin{array}{l}\text { Search \& } \\
\text { Evaluation }\end{array}$} & Pearson Correlation & $.729^{* *}$ & $.666^{* *}$ & 1 & $.736^{* *}$ \\
\cline { 2 - 6 } & Sig. (2-tailed) & .000 & .000 & & .000 \\
\cline { 2 - 6 } & $\mathrm{N}$ & 163 & 163 & 163 & 163 \\
\hline \multirow{3}{*}{ Reducing Risk } & Pearson Correlation & $.676^{* *}$ & $.633^{* *}$ & $.736^{* *}$ & 1 \\
\cline { 2 - 6 } & Sig. (2-tailed) & .000 & .000 & .000 & \\
\cline { 2 - 6 } & $\mathrm{N}$ & 163 & 163 & 163 & 163 \\
\hline
\end{tabular}

**. Correlation is significant at the 0.01 level (2-tailed).

Source: Author's Calculations 
The table suggests that Pearson's correlation coefficient between WOM and Search \& Evaluation is 0.729 . this depicts a positive correlation, which indicates a direct relationship. The correlation between the two factors is relatively higher. The results are significant as the 2-tailed significance value is 0.000 , which is less than 0.005 .

The null hypothesis is rejected, and the alternative hypothesis is accepted.

c. Correlation between WOM and Reduction of Risk

$\mathrm{H}_{0}$ : There is no significant correlation between WOM and Reduction of Risk

$\mathrm{H}_{3}$ : There is a significant correlation between WOM and Reduction of Risk

The table suggests that Pearson's correlation coefficient between WOM and Reduction of Risk is 0.676; this depicts a positive and high correlation indicating a direct relationship. Any value above 0.5 indicates a high correlation. The results are significant as the 2tailed significance value is 0.000 , which is less than 0.005 .

The null hypothesis is rejected, and the alternative hypothesis is accepted.

\section{Regression Tests \\ Regression between WOM and Brand Perception}

The regression model between WOM and Brand Perception indicates that WOM is the independent variable, and Brand Perception is the dependent variable. The $\mathrm{R}^{2}$ value, in this case, the R2 value is 0.461 , which implies $46.1 \%$ of the variation in brand perception, is explained by WOM, which is a relatively significant percentage. The regression model can explain or account for $46 \%$ of the variance in Brand Perception.

The ANOVA table measures whether the regression equation is the best fit for the above-collected data. The value depends on the significance level. If the value of significance is lower than 0.005 , it is the line of best fit.

In this case, the significance value is 0.000 , which is lesser than 0.005 , indicating the best fit line. It also stipulates that the regression model correctly predicts the dependent variable, that is, brand perception.

The above co-efficient table gives us the values to formulate the regression equation. The equation is $y=m x+c$, where' $x$ ' and ' $y$ 'indicate the independent and dependent variable, ' $\mathrm{m}$ ' is

Table 4.3.1: Model Summary (WOM and Brand Perception)

\begin{tabular}{|l|c|c|c|c|}
\hline Model & $\mathrm{R}$ & $\mathrm{R}$ Square & Adjusted R Square & Std. Error of the Estimate \\
\hline 1 & $.679^{\mathrm{a}}$ & .461 & .458 & .55049 \\
\hline
\end{tabular}

a. Predictors: (Constant), WOM Average

Source: Author's Calculations

Table 4.3.2 : ANOVA (WOM and Brand Perception)

\begin{tabular}{|l|l|c|c|c|c|c|}
\hline \multicolumn{2}{|l|}{ Model } & Sum of Squares & Df & Mean Square & F & Sig. \\
\hline \multirow{3}{*}{1} & Regression & 41.750 & 1 & 41.750 & 137.770 & $.000^{\mathrm{b}}$ \\
\cline { 2 - 7 } & Residual & 48.789 & 162 & .303 & & \\
\cline { 2 - 7 } & Total & 90.539 & 163 & & & \\
\hline
\end{tabular}

a. Dependent Variable: Brand Perception Average b. Predictors: (Constant), WOM Average

Source: Author's Calculations

Table 4.3.3: Co-efficient (WOM and Brand Perception)

\begin{tabular}{|l|l|c|c|c|c|c|}
\hline \multicolumn{2}{|c|}{} & \multicolumn{2}{|c|}{$\begin{array}{c}\text { Unstandardized } \\
\text { Coefficients }\end{array}$} & $\begin{array}{c}\text { Standardized } \\
\text { Coefficients }\end{array}$ & & \\
\cline { 3 - 5 } \multicolumn{2}{|c|}{ Model } & B & Std. Error & Beta & $\mathrm{t}$ & Sig. \\
\hline 1 & (Constant) & .497 & .248 & & 2.002 & .047 \\
\cline { 2 - 7 } & WOM Average & .826 & .070 & .679 & 11.738 & .000 \\
\hline
\end{tabular}

a. Dependent Variable: Brand Perception Average

Source: Author's Calculations 
the slope or coefficient, and ' $c$ ' is the constant. In this case, the regression equation (line of best fit) is as follows:

Brand Perception $=0.826($ WOM $)+0.497$

\subsection{Regression between WOM and Search \& Evaluation}

Table 4.4.1: Model Summary (WOM and Search \& Evaluation)

\begin{tabular}{|l|c|c|c|c|}
\hline Model & $\mathrm{R}$ & $\begin{array}{c}\mathrm{R} \\
\text { Square }\end{array}$ & $\begin{array}{c}\text { Adjusted } \\
\text { R Square }\end{array}$ & $\begin{array}{c}\text { Std. Error } \\
\text { of the } \\
\text { Estimate }\end{array}$ \\
\hline 1 & $.729^{\mathrm{a}}$ & .532 & .529 & .58131 \\
\hline
\end{tabular}

a. Predictors: (Constant), WOM Average

Source: Author's Calculations

Table 4.4.2: ANOVA (WOM and Search \& Evaluation)

\begin{tabular}{|c|l|c|c|c|c|c|}
\hline \multicolumn{2}{|c|}{ Model } & $\begin{array}{c}\text { Sum of } \\
\text { Squares }\end{array}$ & df & $\begin{array}{c}\text { Mean } \\
\text { Square }\end{array}$ & F & Sig. \\
\hline \multirow{2}{*}{1} & Regression & 61.856 & 1 & 61.856 & 183.051 & $.000^{\mathrm{b}}$ \\
\cline { 2 - 7 } & Residual & 54.405 & 161 & .338 & & \\
\hline & Total & 116.261 & 162 & & & \\
\hline
\end{tabular}

Source: Author's Calculations

The $\mathrm{R}^{2}$ value for WOM and Search \& Evaluation is 0.532 , which indicates that WOM is responsible for $53.2 \%$ of the variance occurring in Search \& Evaluation. The regression model explains $53 \%$ of the variance, showing that the values are relatively closely located to the line of a good fit.

The ANOVA significance value is 0.000 , which is below 0.005, indicating that the model predicts Search \& Evaluation reasonably well, and the results are statistically significant. The regression equation derived out of this model will display a line of best fit.

Table 4.4.3: Co-efficient (WOM and Search \& Evaluation)

\begin{tabular}{|c|c|c|c|c|c|c|}
\hline & \multirow{2}{*}{ Model } & \multicolumn{2}{|c|}{$\begin{array}{l}\text { Unstandardize } \\
\text { d Coefficients }\end{array}$} & \multirow{2}{*}{$\begin{array}{c}\text { Standardized } \\
\text { Coefficients } \\
\text { Beta }\end{array}$} & \multirow{2}{*}{$t$} & \multirow{2}{*}{$\begin{array}{c}\text { Sig } \\
.\end{array}$} \\
\hline & & B & $\begin{array}{l}\text { Std. } \\
\text { Error }\end{array}$ & & & \\
\hline \multirow[t]{2}{*}{1} & (Constant) & -.067 & .262 & & $\begin{array}{c}- \\
.25 \\
7 \\
\end{array}$ & .798 \\
\hline & $\begin{array}{c}\text { WOM } \\
\text { Average }\end{array}$ & 1.006 & .074 & .729 & $\begin{array}{l}13 . \\
530\end{array}$ & .000 \\
\hline
\end{tabular}

Source: Author's Calculations

The regression equation (line of best fit) for WOM and Search \& Evaluation is as follows: Search \& Evaluation $=1.006($ WOM $)-0.067$

\subsection{Regression between WOM and Reduction of Risk}

Table 4.5.1: Model Summary (WOM and Reduction of Risk)

\begin{tabular}{|c|c|c|c|c|}
\hline Model & $\mathrm{R}$ & $\begin{array}{c}\mathrm{R} \\
\text { Square }\end{array}$ & $\begin{array}{c}\text { Adjusted } \\
\text { R Square }\end{array}$ & $\begin{array}{c}\text { Std. Error } \\
\text { of the } \\
\text { Estimate }\end{array}$ \\
\hline 1 & $.676^{\mathrm{a}}$ & .456 & .453 & .54550 \\
\hline
\end{tabular}

a. Predictors: (Constant), WOM Average

Source: Author's Calculations

Table 4.5.2: ANOVA (WOM and Reduction of Risk)

\begin{tabular}{|c|l|c|c|c|c|c|}
\hline \multicolumn{2}{|c|}{ Model } & $\begin{array}{c}\text { Sum of } \\
\text { Squares }\end{array}$ & Df & $\begin{array}{l}\text { Mean } \\
\text { Square }\end{array}$ & F & Sig. \\
\hline \multirow{2}{*}{1} & Regression & 40.21 & 1 & 40.21 & 135.129 & $.000 \mathrm{~b}$ \\
\cline { 2 - 8 } & Residual & 47.908 & 161 & 0.298 & & \\
\cline { 2 - 8 } & Total & 88.118 & 162 & & & \\
\hline
\end{tabular}

a. Dependent Variable: Reducing Risk Average

b. Predictors: (Constant), WOM Average

Source: Author's Calculations

Table 4.5.3: Coefficients (WOM and Reduction of Risk)

\begin{tabular}{|c|c|c|c|c|c|c|}
\hline \multirow{2}{*}{\multicolumn{2}{|c|}{ Model }} & \multicolumn{2}{|c|}{$\begin{array}{c}\text { Unstandardized } \\
\text { Coefficients }\end{array}$} & \multirow{2}{*}{$\begin{array}{c}\begin{array}{c}\text { Standardized } \\
\text { Coefficients }\end{array} \\
\text { Beta }\end{array}$} & \multirow[b]{2}{*}{$\mathrm{t}$} & \multirow[b]{2}{*}{ Sig. } \\
\hline & & B & $\begin{array}{l}\text { Std. } \\
\text { Error }\end{array}$ & & & \\
\hline \multirow[t]{2}{*}{1} & (Constant) & .715 & .246 & & 2.906 & .004 \\
\hline & $\begin{array}{c}\text { WOM } \\
\text { Average }\end{array}$ & .811 & .070 & .676 & 11.624 & .000 \\
\hline
\end{tabular}

a. Dependent Variable: Reducing Risk Average

Source: Author's Calculations

The $\mathrm{R}^{2}$ value, in this case, is 0.456 , which implies that $45.6 \%$ of the variance in Reducing Risk factors are explained by the regression model, caused by WOM.

The ANOVA significance value is 0.000 , which is below 0.005, indicating that the model predicts Risk Reduction reasonably well, and the model derives a line of best fit. 
As per the co-efficient from the above table, the regression equation for the following will be as follows:

Risk Reduction $=0.811(\mathrm{WOM})+0.715$

\section{DISCUSSIONS}

This study's primary objective was to determine whether there was a significant relationship between Word-of-mouth marketing and Consumer buying behaviour, specifically to the Indian cosmetics industry.

The majority of Indian women are inclined to buy cosmetics in person, from actual stores, compared to online platforms and websites. ANOVA tests also concluded that there was a strong relationship between age and WOM. The variances in WOM can be explained through a period or can be attributed to age as a factor. How older women engage in WOM is different from how younger women participate in WOM. Younger women have more access to technology and an inclination to social media. The impact of positive WOM is inherently different from the effects of negative WOM. Although the impact of positive WOM on consumer purchase decisions is higher, the number of comments/suggestions made under negative WOM is higher. Consumer expresses displeasure with a product commonly, but take into account only positive aspects while purchasing a product. Consumers mostly indulge in WOM or consider others' opinions or suggestions to reduce search \& evaluation effort and reduce the risk of bad choices. Impulse buying the case of cosmetics occurs occasionally but leads to customers feeling a high risk of uncertainty.

When it comes to cosmetics, the consumer does not spend a large amount of time researching a product by themselves, as they'd instead confer with their friends or family. The impact of WOM is higher when consumers are attempting to purchase new cosmetic products that they have not used before. While repeating the purchase of previously used cosmetics, WOM, or any other marketing forms are unaccounted for. The most prominent way in which women engage in WOM when it comes to cosmetics is through recommendations. Whenever they are contented or impressed by a product, they recommend it to friends or family or engage in a conversation about it. Women tend to trust their friends' opinions more than that of family or relatives when it comes to cosmetics. This is usually justified in the case where women have friends of a similar age group and background.

The research also concluded that when it comes to cosmetics, the power of influence of traditional forms of mass marketing is slightly more prominent than the power of WOM. Although women indulge in WOM, their buying behaviour remains influenced mainly by old-school marketing techniques. This is one of the primary reasons why most cosmetic brands in India focus on TV advertisements, discounts, and other promotional offers. Nonetheless, the elasticity attached to WOM when companies acquire new consumers through WOM is higher when compared to situations where companies reach new consumers through traditional advertising. Companies like Loreal, Maybelline, and Lakme are focused on viral marketing techniques, primarily through social media. The use of social media influencers and sponsored ads, and celebrity endorsements allows companies to generate WOM without contributing directly to the process. Companies and managers that are interested in making WOM a primary marketing tool have multiple things to consider. They need to understand and analyse the factors that impact WOM in this industry. They must comprehend how WOM can be deliberately generated but made to appear like it's naturally occurring to the consumer, which is when it's most effective. The segmentation of the market also affects the impact or use of WOM in these segments. In luxury segments where companies like Estee-Lauder, Clinique, Chanel operate, there is little scope for mass marketing and WOM. Marketing occurs through its brand image and the hype around the quality of the brand.

\section{Theoretical Implications}

Because in the cosmetics industry, consumers are influenced by both traditional and WOM marketing techniques alike, companies need to formulate strategies that provide dual benefits to them. Each company can conduct research to analyse which particular method works for them and which does not. As seen in many cases, even in the cosmetics industry, whenever companies launch a new product or 
collection, they indulge in the extensive use of social media to make their product number one on the trending list; this 'trending list' reflects that a large number of people are talking about the product or the topic. Hence, it becomes crucial for managers to not just 'allow' WOM to occur but to formulate strategies to manage that WOM so that it results in positive outcomes for a company.

\section{Managerial Implications}

In the Indian cosmetics industry, the leading players that operate are likely to design such push WOM strategies to get people talking about the product. This creates a buzz or hype around the product. As the study found that most women base their brand perception on the WOM of the products, it is suggested that companies indulge in maximizing WOM. Usually, companies do this through coherent social media strategies that allow people to submit. Most platforms like Instagram, which has 'influencers,' are preferred by companies because they have many followers and post regular advertisements and suggestions. If a well-known celebrity endorses that she uses a particular brand's product for skincare, her followers will most likely jump on the bandwagon and speak about it. Reading such reviews and suggestions online becomes a part of eWOM. The consumers end up being a part of the eWOM movement of the company, without realizing it/unintentionally

\section{Limitations and Future Scope Of Work}

Several factors limited the current study, but the study's significance allows it to be generalized to the population. The lack of data also prevented us from studying the difference between generating WOM and consuming or utilizing WOM. This study has given us insight into the Indian cosmetic industry's operation, where there are multiple players and high competition. This requires them to utilize various unique marketing strategies, and WOM is becoming preferred among them. The study conducted has its limitations in terms of the sample size and the sample demographics while generalizing India's results. Nonetheless, the results obtained have been significant, which establishes a strong correlation between Word-of-mouth Marketing and Consumer Behaviour in the Indian cosmetics market. Further, this research can be expanded to other fashion Industries to see the implication of WOM on brand perception

\section{CONCLUSION}

As the study has established a concrete relationship between the two factors tested, it opens doors for an arena of future studies. As it is, WOM is a domain that has not been given the importance that it exhibits, so the scope of future research is very high.

A prime example would be Maybelline's marketing campaign for their new liquid matte lipstick range, where they advertise the 36 shades that they exclusively provide. They also sponsor ads on Instagram for the same products that allow consumers to find their ideal shade based on their mood and preferred colour. This was a direct form of traditional marketing, but it provided an additional benefit for consumers talking about this product. The unique ad campaign was talked about on online forums creating a social media buzz. The company didn't exclusively plan or pay for the additional benefit, and it occurred inadvertently.

Maybelline's 'Fit me' foundation strategy was a huge hit because they stressed the availability of multiple shades for the different Indian skin tones, which were earlier not available. Companies like Lakme, Loreal, and Maybelline have used celebrity endorsements to trigger or cause a buzz around their product, leading to a push WOM phenomenon. Whereas companies like MAC and Sephora, which tend to the higher sections of society, have not indulged in intentional WOM marketing. Considering that these companies cater to the upper classes' needs, they might not require mass advertisements and hype.

The more luxury-oriented brands like EsteeLauder, Clinique, and Bobbi Brown do not engage too much in any marketing, let alone WOM. These brands are driven entirely based on brand image and value. They have created a firm brand name that is associated with quality and requires no expenditure on marketing. Although such companies do not intentionally create WOM buzz, they are affected by the natural WOM that occurs. Consumers tend to recommend these brands to others and consider such reviews due to the established brand name. These companies 
become the epitome of the high correlation between WOM and Brand Perception/Image.

As concluded and suggested by KraigherKrainer, Überwimmer, Costa, \& Zehetner (The Hidden Impact of Word-Of-Mouth: A System Dynamics Approach, 2017), companies need to take into account WOM while introducing a new product into the market. As WOM has become a deciding factor or phenomenon in today's market, it can be either the reason for the new product's success or unprecedented failure. The most important activity that companies can teach is to conduct comprehensive market research to understand how to use WOM in the most effective way to lead to the newly launched product's success. Another important aspect that companies can fulfil by undertaking WOM strategies is to disseminate information. Instead of directly providing information about a product through the usual traditional marketing channels, companies can undertake 'viral marketing' techniques to share information vital to consumer buying behaviour. In most cases, consumers find out the full extent of a product's utility and its features through WOM. While casually talking about the product, consumers mention the utility or functions and features of the product. In many cases, a particular part will result in an additional purchase, wherein the customer gets impressed or drawn in by the characteristic.

In light of WOM's importance, the researcher also suggests that consumers need to be proactive in analysing the sources of WOM to establish credibility.

\section{REFERENCES}

Barber, P., \& Wallace, L. (2018). The Power of Word-of-Mouth Marketing. American Library Association, 36-39.

Belk, R. W. (1988, September ). Possessions and the Extended Self. Journal of Consumer Research, 15(2), 139-168. Retrieved from https://doi.org/10.1086/209154

Charlett, D., Garland, R., \& Marr, N. (1995). How Damaging is Negative Word of Mouth? Marketing Bulletin, 42-50.

Chung, C. M., \& Darke, P. R. (2006). The Consumer as Advocate: Self-Relevance,
Culture, and Word-of-Mouth. Marketing

Letters, 7(7), 269-279.

Chauhan, S., Banerjee, R., \&amp; Banerjee, S. (2019). The Impact of Website Quality and Reputation on Purchasing Intention Towards Online Shopping. Journal Of Content, Community And Communication, 10(9). doi: 10.31620/jccc.12.19/15.

Dean, D. H., \& Lang, J. M. (2008). Comparing three signals of service quality. Journal of Services Marketing, 22(1), 49-58.

East, R., Hammond, K., \& Lomax, W. (2008., $04)$. Measuring the impact of positive and negative word of mouth on brand purchase probability. International Journal of Research in Marketing, 25(1), 215-224.

Fazio, R. H., \& Towles-Schwen, T. (1999). The MODE model of attitude-behavior processes. In J. W. Sherman, \& G. Press. (Ed.), Dual process theoriesof the social mind. (pp. 97-116). New York: Guilford Press.

Gabeur, H. (2015). Consumer's behavior facing word-of-mouth and the impact on marketing point of view: exploratory analysis. ISCTE Business School.

Godes, D., \& Mayzlin, D. (2004). Using Online Conversations to Study Word-of-Mouth Communication. Marketing Sciences, 23(4), 545-560. Retrieved september 25th , 2019

Keller, E., \& Libai, B. (2009). A holistic approach to the measurement of WOM: Its impact on consumer's decisions. Israel: ESOMAR 2009 12 .

Kraigher-Krainer, J., Überwimmer, M., Costa, Y., \& Zehetner, A. (2017). The Hidden Impact of Word-Of-Mouth: A System Dynamics Approach. University of Applied Sciences Upper Austria, Steyr, Austria , 117.

Kraigher-Krainer, J., Überwimmer, M., Costa, Y., \& Zehetner, A. (2017). The Hidden Impact of Word-Of-Mouth: A System Dynamics Approach . Marketing Science \& Inspirations, 111-120.

Robert V. Kozinets, K. d. (2010). Networked Narratives: Understanding Word-ofMouth Marketing in Online Communities . American Marketing Assosciation.

Schiffman, L., \& Kanuk, L. (2015). Consumer Behavior (11th Edition ed.). Pearson. 
Trusov, M., Bucklin, R. E., \& Pauwels, K. (2009, September ). Effects of Word-ofMouth versus Traditional Marketing: Findings from an Internet Social Networking Site. Journal of Marketing, 73, 90-102.
Walker, C. (1995). Word of mouth . American Demographics, 38-44. 